\title{
Reef sponges facilitate the transfer of coral-derived organic matter to their associated fauna via the sponge loop
}

\author{
Laura Rix ${ }^{1, *}$, Jasper M. de Goeij ${ }^{2}$, Dick van Oevelen ${ }^{3}$, Ulrich Struck ${ }^{4}$, \\ Fuad A. Al-Horani ${ }^{5}$, Christian Wild ${ }^{6, * *}$, Malik S. Naumann ${ }^{6,7, * *}$ \\ ${ }^{1}$ GEOMAR Helmholtz Centre for Ocean Research Kiel, RD3 Marine Microbiology, Düsternbrooker Weg 20, 24105 Kiel, Germany \\ ${ }^{2}$ Department of Freshwater and Marine Ecology, Institute for Biodiversity and Ecosystem Dynamics, \\ University of Amsterdam, PO Box 94248, 1090 GE Amsterdam, The Netherlands \\ ${ }^{3}$ Department of Estuarine and Delta Systems, NIOZ Royal Netherlands Institute for Sea Research, and Utrecht University, \\ PO Box 140, 4400 AC Yerseke, The Netherlands \\ ${ }^{4}$ Museum für Naturkunde, Leibniz Institute for Evolution and Biodiversity Science, Invalidenstr. 43, 10115 Berlin, Germany \\ ${ }^{5}$ The University of Jordan - Aqaba and Marine Science Station, PO Box 2595, Aqaba 77110, Jordan \\ ${ }^{6}$ Faculty of Biology and Chemistry (FB 2), University of Bremen, UFT, Leobener Str. 6, 28359 Bremen, Germany \\ ${ }^{7}$ Coral Reef Ecology Group, Leibniz Center for Tropical Marine Research (ZMT), Fahrenheitstr. 6, 28359 Bremen, Germany
}

\begin{abstract}
The high biodiversity of coral reefs results in complex trophic webs where energy and nutrients are transferred between species through a multitude of pathways. Here, we hypothesize that reef sponges convert the dissolved organic matter released by benthic primary producers (e.g. corals) into particulate detritus that is transferred to sponge-associated detritivores via the sponge loop pathway. To test this hypothesis, we conducted stable isotope $\left({ }^{13} \mathrm{C}\right.$ and $\left.{ }^{15} \mathrm{~N}\right)$ tracer experiments to investigate the uptake and transfer of coral-derived organic matter from the sponges Mycale fistulifera and Negombata magnifica to 2 types of detritivores commonly associated with sponges: ophiuroids (Ophiothrix savignyi and Ophiocoma scolopendrina) and polychaetes (Polydorella smurovi). Findings revealed that the organic matter naturally released by the corals was indeed readily assimilated by both sponges and rapidly released again as sponge detritus. This detritus was subsequently consumed by the detritivores, demonstrating transfer of coralderived organic matter from sponges to their associated fauna and confirming all steps of the sponge loop. Thus, sponges provide a trophic link between corals and higher trophic levels, thereby acting as key players within reef food webs.
\end{abstract}

KEY WORDS: Coral mucus $\cdot$ Reef trophic web $\cdot$ Detritus $\cdot$ Sponge loop $\cdot$ Detritivore $\cdot$ Trophic interactions $\cdot$ Interspecific associations

\section{INTRODUCTION}

Highly biodiverse tropical coral reefs are characterized by complex trophic webs and intricate networks of positive and negative interspecific interactions that are fundamental for understanding reef ecosystem functioning (Glynn 2004, Briand et al. 2016, Harborne et al. 2017). Due to high levels of pre-

*Corresponding author: laura.n.rix@gmail.com

${ }^{* *}$ These authors contributed equally to this work dation and intense competition for space and resources, the exploitation of other organisms as living habitat is a common strategy on coral reefs (e.g. Duffy 1992, Munday et al. 1997, Elliott \& Mariscal 2001). Sponges, an abundant faunal component of coral reefs, are amongst the most widely exploited, harbouring an exceptionally diverse array of crustaceans, molluscs, bryozoans, polychaetes, cnidari-

(C) The authors 2018. Open Access under Creative Commons by Attribution Licence. Use, distribution and reproduction are unrestricted. Authors and original publication must be credited. 
ans, echinoderms (including ophiuroids), and fishes (e.g. Pearse 1950, Wesztinga \& Hoetjes 1981, Duarte \& Nalesso 1996, Wulff 2006). Many of these associations are opportunistic and transient, but others are obligate, or even species-specific (Henkel \& Pawlik 2005), forming relationships ranging from mutualism (Meroz \& Ilan 1995) to parasitism (Pawlik 1983, Duuriš et al. 2011). However, most of these relationships, including potential trophic interactions, are poorly characterized.

Sponges not only offer habitat and physical protection for their associates, but can also provide food through predation on sponge tissue (Pawlik 1983, Oshel \& Steele 1985, Duriš et al. 2011), exploitation of the enhanced particle flow induced by sponge pumping (Westinga \& Hoetjes 1981, Costello \& Myers 1987), or deposit-feeding on detritus that settles on the sponge surface (Hendler 1984, Henkel \& Pawlik 2005). Sponges can also actively generate detritus that may be utilized by reef fauna (Hammond \& Wilkinson 1985, de Goeij et al. 2013). Recently, it was hypothesized that by taking up dissolved organic matter (DOM) and converting it into particulate detritus, sponges enable the transfer of the energy and nutrients in DOM to higher trophic levels on coral reefs via a pathway defined as the 'sponge loop' (de Goeij et al. 2013, Rix et al. 2016, 2017). Benthic primary producers are the main producers of labile DOM on reefs, as they release large quantities of the carbon they fix into the surrounding water as DOM (Crossland 1987, Barrón \& Duarte 2009, Haas et al. 2011). Corals, for example, devote up to $\sim 40 \%$ of their net photosynthetic output into the release of coral mucus (Crossland et al. 1980, Haas et al. 2011, Tremblay et al. 2012). This mucus is released in both dissolved and particulate forms (Crossland 1987, Naumann et al. 2010), although the majority of the particulate mucus also subsequently dissolves into the surrounding water, further contributing to the reef DOM pool (Wild et al. 2004). This DOM pool represents one of the largest available organic matter pools on corals reefs, and yet its energy and nutrients remain largely inaccessible to most reef fauna as a major food source. Reef sponges, however, are not only able to take up natural reef DOM at high rates, but DOM can account for the majority (up to $\sim 90 \%$ ) of their total heterotrophic carbon uptake (Yahel et al. 2003, de Goeij et al. 2008, Mueller et al. 2014a, McMurray et al. 2016, Morganti et al. 2017). Furthermore, up to $\sim 40 \%$ of the DOM assimilated by sponges is subsequently released as detritus (de Goeij et al. 2013, Rix et al. 2016, 2017), a substrate that is consumed by a wide range of reef fauna (e.g. Glynn 2004). Sponges therefore convert reef DOM into a food source that would be more readily accessible to their detritus-feeding associated fauna. Consequently, we hypothesize that sponges not only generate food for their associated detritivores through the production of sponge detritus, but also provide a direct trophic link between corals and sponge-associated detritivores that allows these associates ready access to the dissolved energy and nutrients produced by corals.

To test this hypothesis, we conducted 2 stable isotope tracer experiments with ${ }^{13} \mathrm{C}$ - and ${ }^{15} \mathrm{~N}$-labelled corals to follow the transfer of coral-derived organic matter (i.e. coral mucus) through each step of the sponge loop: (1) uptake and assimilation of naturally released coral mucus by the sponges, (2) release of assimilated coral mucus by the sponges as sponge detritus and (3) uptake of sponge detritus by 2 types of detritivores commonly associated with reef sponges: polychaetes and ophiuroids. First, we investigated the trophic transfer of coral mucus through the branching sponge Negombata magnifica to its associated spionid polychaete Polydorella smurovi. Spionid polychaetes are deposit and suspension feeders lacking mechanisms for predatory feeding, and most known species of Polydorella are associated with sponges (Taghon et al. 1980, Dauer et al. 1981, Williams \& McDermott 1997, Williams 2004). Secondly, we examined the transfer of coral mucus through the encrusting sponge Mycale (Carmia) fistulifera to the detritus-feeding ophiuroids Ophiothrix savignyi and Ophiocoma scolopendrina (Magnus 1965, Warner \& Woodley 1975, Hendler 1984), which commonly inhabit sponges (O. savignyi) (James \& Pearse 1969) and rubble on reef flats (O. scolopendrina) (Magnus 1965).

\section{MATERIALS AND METHODS}

\section{Study site and organism collection}

This study was conducted at the Marine Science Station (MSS) in Aqaba, Jordan (northern Gulf of Aqaba, Red Sea; $29^{\circ} 27^{\prime} \mathrm{N}, 34^{\circ} 58^{\prime}$ E) during September and October 2013. Sampling was carried out on the $\sim 1 \mathrm{~km}$ long fringing reef in front of the MSS between 8 and $20 \mathrm{~m}$ water depth by SCUBA. Free-living fungiid corals (genera: Fungia, Ctenactis and Herpolitha; $\mathrm{n}=30$ ) were collected as they can be removed from the reef without physical damage and produce large quantities of coral mucus (Naumann et al. 2010). Corals were transferred to the MSS without air exposure and maintained in running-seawater facilities 
(>1000 l) for at least $72 \mathrm{~h}$ prior to the start of experiments. Two abundant sponge species were collected, the encrusting sponge Mycale (Carmia) fistulifera $\left(20 \pm 8 \mathrm{~cm}^{3}\right.$ fragments were chiselled from dead branching corals) and the branching sponge Negombata magnifica (small branches of $67 \pm 22 \mathrm{~cm}^{3}$ were cut), and maintained in $100 \mathrm{l}$ flow-through aquaria for at least $1 \mathrm{wk}$ of acclimation. Polydorella smurovi polychaetes were collected by cutting branches of densely infested $N$. magnifica specimens. The ophiuroids were collected from sponges (Ophiothrix savignyi) and the reef flat (Ophiocoma scolopendrina). O. Scolopendrina was included for comparison of a typically non-sponge-associated detritivore that utilizes a similar feeding mode (Magnus 1965, and therefore may be representative of a strictly transient or opportunistic associate that only rarely encounters sponges). Detritivores were acclimated with their host sponges for $48 \mathrm{~h}$ prior to experimentation.

\section{Stable isotope tracer experiment (coral-coral mucus-sponge-detritus-detritivore)}

Stable isotope $\left({ }^{13} \mathrm{C}\right.$ and $\left.{ }^{15} \mathrm{~N}\right)$ labelling of corals was conducted over $8 \mathrm{~d}$ as described by Rix et al. (2016). Briefly, corals were labelled in $100 \mathrm{l}$ aquaria to which the seawater flow-through was stopped and $36 \mathrm{mg} \mathrm{l}^{-1}$ $\mathrm{NaH}^{13} \mathrm{CO}_{3}$ and $1 \mathrm{mg} \mathrm{l}^{-1} \mathrm{Na}^{15} \mathrm{NO}_{3}$ (Cambridge Isotopes, $98 \%{ }^{13} \mathrm{C}$ and ${ }^{15} \mathrm{~N}$ ) were added. Aquarium pumps maintained water circulation and gas exchange until seawater flow-through was resumed overnight $(8 \mathrm{~h})$. Water temperature was maintained within $\pm 1^{\circ} \mathrm{C}$ of in situ conditions by placing aquaria in a flow-through raceway (flow rate $\sim 1000 \mathrm{l} \mathrm{h}^{-1}$ ). After the final day of labelling, the corals were transferred to the raceway and rinsed in fresh flowing seawater overnight to remove any unincorporated label. Coral mucus was collected from a sub-set of the corals $(n=6)$ by brief ( $2 \mathrm{~min}$ ) air exposure and frozen at $-80^{\circ} \mathrm{C}$ for subsequent stable isotope analysis. Corals were transferred to the experimental set-up for the subsequent tracer experiment the following morning.

The trophic transfer of mucus from the ${ }^{13} \mathrm{C}$ - and ${ }^{15} \mathrm{~N}$-labelled corals through the sponge tissue and detritus to sponge-associated detritivores was investigated using six 2-tiered, flow-through aquaria setups, consisting of paired upper and lower aquaria (100 l each) connected via constant water flow. The upper aquaria (light levels $\sim 120 \mu \mathrm{mol}$ quanta $\mathrm{m}^{-2} \mathrm{~s}^{-1}$ ) were supplied with fresh-pumped reef water at a rate of $\sim 101 \mathrm{~min}^{-1}$, which then flowed into the lower aquaria. Labelled corals ( $\mathrm{n}=10$ per aquarium) were maintained in 3 of the upper aquaria, while the remaining 3 upper aquaria served as coral-free controls. The lower aquaria contained sponges cleared of their associated detritivores; either N. magnifica or M. fistulifera ( $\mathrm{n}=4$ per aquarium). The set-up was designed to mimic natural in situ conditions as closely as possible, and corals were allowed to release mucus at natural rates without manipulation. Thus, here we consider the transfer of bulk mucus and do not differentiate between particulate or dissolved fractions. To ensure conditions for the first step of the sponge loop were met (i.e. the uptake of dissolved mucus by the sponges), samples for dissolved organic carbon (DOC) and bacterioplankton were taken from the upper aquaria $(\mathrm{n}=3-6$ per aquarium and $\mathrm{n}=9-18$ per treatment) to compare differences between the treatment and control aquaria to verify DOC release by the corals. To determine DOC uptake by the sponges, the flow-through from the coral aquaria to the sponge aquaria was briefly stopped (30 min) and initial DOC and bacterioplankton samples were taken from each sponge tank and then resampled after 30 min to measure uptake by the sponges ( $\mathrm{n}=3$ per aquaria, $\mathrm{n}=9$ per treatment). The flow rate to the upper aquaria ( 10 l $\min ^{-1}$ ) ensured the set-up was replaced with fresh seawater every $10 \mathrm{~min}$ in order to supply the sponges with sufficient food as well as to prevent bacterioplankton growth and potential bacterial-mediated transfer of coral mucus to the sponges. After $5 \mathrm{~d}$ exposure to seawater flowing from the aquaria containing the labelled corals, 1 sponge per tank was removed, rinsed in label-free seawater for $10 \mathrm{~min}$, and frozen at $-80^{\circ} \mathrm{C}$ for stable isotope analysis ( $\mathrm{n}=3$ per treatment). The corals were removed and all aquaria were thoroughly cleaned and flushed with fresh flowing seawater for $2 \mathrm{~h}$ to eliminate any labelled organic matter originating from the corals prior to introducing the detritivores in order to ensure any subsequent enrichment of ${ }^{13} \mathrm{C}$ and ${ }^{15} \mathrm{~N}$ could be attributed to the sponges. Detritivores were then transferred onto the remaining experimental sponges. $P$. smurovi specimens were transferred with a pipette onto the surface of $N$. magnifica where they quickly re-established themselves on the sponge surface. The ophiuroids $O$. savignyi and $O$. scolopendrina ( $\mathrm{n}=4$ per aquarium, $\mathrm{n}=12$ per treatment) were introduced to the aquaria with $M$. fistulifera and immediately took refuge in crevices inside the sponges. One and $5 \mathrm{~d}$ after the addition of the detritivores, detritus was collected from the surface of each sponge with a pipette, pooled by aquarium for stable isotope analysis $(\mathrm{n}=2$ per aquarium, $\mathrm{n}=6$ per treat- 
ment), and frozen at $-80^{\circ} \mathrm{C}$ for isotope analysis. After $5 \mathrm{~d}$, the polychaetes, ophiuroids, and remaining sponges were frozen at $-80^{\circ} \mathrm{C}$ for isotope analysis. Due to their small size, polychaetes from each aquarium were pooled onto 1 pre-combusted $\left(450^{\circ} \mathrm{C}, 4 \mathrm{~h}\right)$ $\mathrm{GF} / \mathrm{F}$ filter ( $\mathrm{n}=3$ per treatment).

\section{Sponge detritus production}

To determine detritus production, N. magnifica and $M$. fistulifera specimens were incubated individually in stirred 21 chambers for $3 \mathrm{~h}$ ( $\mathrm{n}=6$ per species) as previously described (Rix et al. 2016). To prevent contamination with previously accumulated detritus or sediment, the sponges were carefully cleaned of all detritus and debris using gentle suction with a small tube a few $\mathrm{mm}$ from the sponge surface without touching or disrupting the sponges. Sponges were then transferred without air exposure to the base plate of the incubation chambers and cleaned again prior to closing the chambers. Incubations without sponges $(n=6)$ served as controls. Initial samples for particulate organic carbon (POC) and nitrogen (PON) were taken at the start of the incubation from the fresh seawater used to fill the chambers $(n=6)$. At the end of the incubation, sponges were carefully removed, and the incubation water was homogenized and $1 \mathrm{l}$ gently vacuum-filtered onto 2 separate pre-combusted GF/F filters (1 each for POC and PON). Filters were dried at $40^{\circ} \mathrm{C}$ for at least $48 \mathrm{~h}$ and stored dry until C:N elemental analysis. Sponge surface area and thickness were measured to determine the sponge volume. Fluxes of POC and PON were corrected for the initial concentrations of POC and $\mathrm{PON}$ in the seawater, and the sponge fluxes were corrected for differences with seawater controls. Rates were then normalized to sponge volume and incubation time and presented as $\mu \mathrm{mol} \mathrm{C}$ or $\mathrm{N} \mathrm{cm}^{-3}$ sponge $\mathrm{d}^{-1}$.

\section{DOC and flow cytometry measurements}

DOC samples were collected in pre-cleaned $60 \mathrm{ml}$ syringes and gently vacuum filtered (maximum pressure $20 \mathrm{kPa}$ ) through pre-combusted GF/F filters directly into $30 \mathrm{ml}$ high-density polyethylene (HDPE) sample bottles using a customized set-up. Syringes, filtration apparatus, and sample bottles were acidwashed in $0.4 \mathrm{M} \mathrm{HCl}$ for $24 \mathrm{~h}$ and rinsed twice with Milli-Q water before sampling. The first $20 \mathrm{ml}$ of sample water was used to rinse the sample bottles
$(2 \times 10 \mathrm{ml})$. The remaining $30 \mathrm{ml}$ was collected, acidified with $80 \mu \mathrm{l}$ of $18.5 \% \mathrm{HCl}$, and stored at $4^{\circ} \mathrm{C}$ in the dark until analysis. Samples were measured using high-temperature catalytic oxidation (HTCO) on a total organic carbon analyser (Shimadzu TOC- $\mathrm{V}_{\mathrm{CPH}}$ ). The instrument was calibrated with a 10 point calibration using serial dilutions of potassium hydrogen phthalate (certified stock solution 1000 ppm Standard Fluka 76067). Deep sea reference (DSR) water

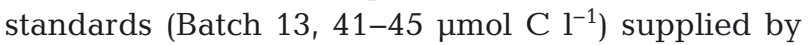
the Consensus Reference Material (CRM) Project (Hansell Lab, University of Miami) were applied as a positive control after every 10 samples to determine the accuracy and precision of the instrument. Each sample was averaged over 5 measurements and analytical precision was $<3 \%$ of the certified value. Bacterioplankton samples $(2 \mathrm{ml})$ were fixed in $0.1 \%$ paraformaldehyde (final concentration) for $30 \mathrm{~min}$ at room temperature, frozen with liquid $\mathrm{N}$, and stored at $-80^{\circ} \mathrm{C}$ until analysis. Abundances of heterotrophic bacteria were quantified on a FACSCalibur flow cytometer (Becton Dickinson, $488 \mathrm{~nm}$ excitation laser). Samples were stained with SYBR Green 1 for 30 min prior to sorting at a flowrate of approximately $0.06 \mu \mathrm{lmin}{ }^{-1}$ for $1 \mathrm{~min}$. Heterotrophic bacteria were gated on a plot of side scatter versus green fluorescence using CellQuestPro (BD Biosciences). The cytometer flow rate was gravimetrically calibrated according to Marie et al. (1999), and all samples were measured on the same day.

\section{Sample treatment and stable isotope analysis}

Sponge tissue, sponge detritus, and ophiuroid tissue samples were lyophilized and homogenized, and subsamples were weighed into silver cups for $\delta^{13} \mathrm{C}$ and $\delta^{15} \mathrm{~N}$ analysis. Samples for $\delta^{13} \mathrm{C}$ were decalcified with $0.4 \mathrm{M} \mathrm{HCl}$ to obtain the organic carbon $\left(\mathrm{C}_{\text {org }}\right)$ fraction. GF/F filters (polychaetes and filters from sponge detritus production incubations) were decalcified in an atmosphere of fuming HCL, re-dried at $40^{\circ} \mathrm{C}$ and folded into silver cups. Isotope ratios and $\mathrm{C}: \mathrm{N}$ content were measured simultaneously using a Flash 1112 EA coupled to a Delta V IRMS via a Conflo IV- interface (Thermo Scientific). Standard deviations of $\mathrm{C}$ and $\mathrm{N}$ content were $<3 \%$ of the concentrations analysed and $<0.15 \%$ for repeated $\delta^{13} \mathrm{C}$ and $\delta^{15} \mathrm{~N}$ measurements of standard material (peptone).

Carbon and nitrogen stable isotope ratios are expressed in delta notation as: $\delta^{13} \mathrm{C}$ or $\delta^{15} \mathrm{~N}(\%)=$ $\left(R_{\text {sample }} / R_{\text {ref }}-1\right) \times 1000$, where $R$ is the ratio of ${ }^{13} \mathrm{C}:{ }^{12} \mathrm{C}$ or ${ }^{15} \mathrm{~N}:{ }^{14} \mathrm{~N}$ in the sample or reference mate- 
rial: Vienna Pee Dee Belemnite for C $\left(R_{\text {ref }}=0.01118\right)$ and atmospheric nitrogen for $\mathrm{N}\left(R_{\mathrm{ref}}=0.00368 \mathrm{~N}\right)$. The incorporation of excess (i.e. above background) ${ }^{13} \mathrm{C}$ and ${ }^{15} \mathrm{~N}$ tracer (see Fig. 1) was calculated by subtracting the background $\delta^{13} \mathrm{C}$ and $\delta^{15} \mathrm{~N}$ values of the control samples from the treatment samples as follows: $\Delta \delta^{13} \mathrm{C}=\delta^{13} \mathrm{C}_{\text {sample }}-\delta^{13} \mathrm{C}_{\text {background }}$ and $\Delta \delta^{15} \mathrm{~N}=$

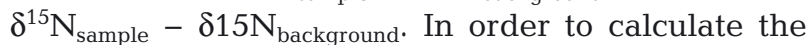
uptake rates of coral mucus by the sponges and sponge detritus by the detritivores (see Fig. 2), the excess fractional abundance of heavy isotope $(E)$ in the sponge and detritivore tissue was calculated as: $E=F_{\text {sample }}-F_{\text {background, }}$ where $F_{\text {sample or background }}=$ $R_{\text {sample or background }} /\left(R_{\text {sample or background }}+1\right)$. The total uptake $(I)$ of ${ }^{13} \mathrm{C}$ and ${ }^{15} \mathrm{~N}$ was then calculated by multiplying $E$ by the $\mathrm{C}_{\text {org }}$ or $\mathrm{N}$ content of the sponge or detritivore tissue. To determine the total $\mathrm{C}\left({ }^{12} \mathrm{C}+\right.$ ${ }^{13} \mathrm{C}$ ) and $\mathrm{N}\left({ }^{14} \mathrm{~N}+{ }^{15} \mathrm{~N}\right)$ incorporated, $I$ was divided by the fractional abundance of either the coral mucus (to determine total uptake rates of coral mucus $\mathrm{C}$ and $\mathrm{N}$ into the sponge tissue) or detritus (to determine the total uptake rates of sponge detritus $\mathrm{C}$ and $\mathrm{N}$ by the detritivores). Rates were then normalized to time and tissue $\mathrm{C}_{\text {org }}$ or $\mathrm{N}$ content of the sponges or detritivores (see Fig. 2).

\section{Data analysis}

Statistical analyses to determine differences in ${ }^{13} \mathrm{C}$ and ${ }^{15} \mathrm{~N}$ enrichment in the control and treatment samples were conducted in PRIMER-E version 6 (Clarke \& Gorley 2006) with the PERMANOVA+ add-on (Anderson et al. 2008) using individual 1-factor permutational multivariate analyses of variance (PERMANOVAs) with Type III (partial) sum of squares and unrestricted permutation of raw data (999 permutations). PERMANOVAs with Monte Carlo tests were used when the sample size could not provide sufficient permutations (i.e. $\mathrm{n}=3$ for polychaetes, Anderson et al. 2008). Generalised linear models (GLM) were used to compare concentrations of DOC and bacterioplankton in the treatment and control aquaria. First, we tested for a potential tank effect within each treatment by running a GLM with 'Tank' as the fixed factor. Since this was not significant, an additional GLM was run with 'Treatment' as the single fixed factor. Assumptions of normally distributed and homogenous residuals were confirmed using $Q Q$ plots and scatter plots of residuals against fitted values, and data were transformed where necessary. Paired $t$ tests were used to determine differences in DOC and bacterioplankton concentrations in the sponge aquaria before and after the flow-through seawater was stopped for $30 \mathrm{~min}$. The treatment and control aquaria were tested separately as they showed different trends for DOC. These statistical tests were carried out in R v. 3.3.3 (R Core Team 2012).

\section{RESULTS}

DOC concentrations were significantly elevated in the treatment aquaria containing the labelled corals (mean $\pm \mathrm{SD}, 83.7 \pm 4.9 \mu \mathrm{M}$ ) compared to the control aquaria without corals $(76.6 \pm 4.7 \mu \mathrm{M})$, demonstrating release of DOC by the labelled corals (GLM: $F_{1,52}$ $=29.1, \mathrm{p}<0.001)$. By contrast, there were no significant differences in the concentrations of bacterioplankton in the treatment and control aquaria (1.84 \pm $0.29 \times 10^{5}$ and $1.83 \pm 0.20 \times 10^{5}$ cells $\mathrm{ml}^{-1}$, respectively; $F_{1,34}=0.05, \mathrm{p}=0.8203$ ), indicating the flow rate was sufficient to prevent coral mucus-fuelled growth of bacteria in the aquaria. When the flowthrough seawater to the sponge aquaria was stopped, there was a significant decrease in bacterioplankton concentrations in both the treatment $(-5.04 \pm 1.22 \times$ $10^{4}$ cells ml $\left.{ }^{-1}\right)$ and control $\left(-4.59 \pm 2.10 \times 10^{4}\right.$ cells $\mathrm{ml}^{-1}$ ) aquaria after $30 \mathrm{~min}$, demonstrating the sponges were actively filtering (paired $t$-test: $t=16.7$, df $=8, \mathrm{p}<0.001$ and $t=8.4$, df $=8, \mathrm{p}<0.001$ for the treatment and control aquaria, respectively). However, DOC concentrations showed a significant decrease only in the treatment aquaria after $30 \mathrm{~min}$ (net DOC flux: $-6.5 \pm 4.4 \mu \mathrm{M}$ DOC; paired $t$-test: $t=$ 5.63, df $=17, \mathrm{p}<0.001$ ), while no changes were observed in the control aquaria (net DOC flux: +1.44 $\pm 5.5 \mu \mathrm{M} ; t=-1.11, \mathrm{df}=17, \mathrm{p}=0.2831$ ). DOC removal by the treatment sponges $(6.5 \pm 4.4 \mu \mathrm{M})$ corresponded with the increase in DOC concentration between the treatment and control aquaria $(7.1 \mu \mathrm{M})$. Thus, the consistent net uptake of DOC only by sponges in the treatment aquaria, where DOC concentrations were initially elevated due to release of DOC by the labelled corals, demonstrates uptake of coral-derived DOC.

After labelling with the stable isotope tracers $\left(\mathrm{NaH}^{13} \mathrm{CO}_{3}\right.$ and $\left.\mathrm{Na}^{15} \mathrm{NO}_{3}\right)$, the corals produced mucus that was enriched in both ${ }^{13} \mathrm{C}$ and ${ }^{15} \mathrm{~N}$ (Fig. 1). The stable isotope tracer experiments confirmed the transfer of this coral-derived $\mathrm{C}$ and $\mathrm{N}$ into the tissue of the 2 sponges Negombata magnifica and Mycale fistulifera, as evidenced by positive (i.e. above background) $\Delta^{13} \mathrm{C}$ and $\Delta^{15} \mathrm{~N}$ values after $5 \mathrm{~d}$ exposure to the ${ }^{13} \mathrm{C}$ - and ${ }^{15} \mathrm{~N}$-labelled corals (Fig. 1). Incorporation rates of coral mucus into sponge tissue were 

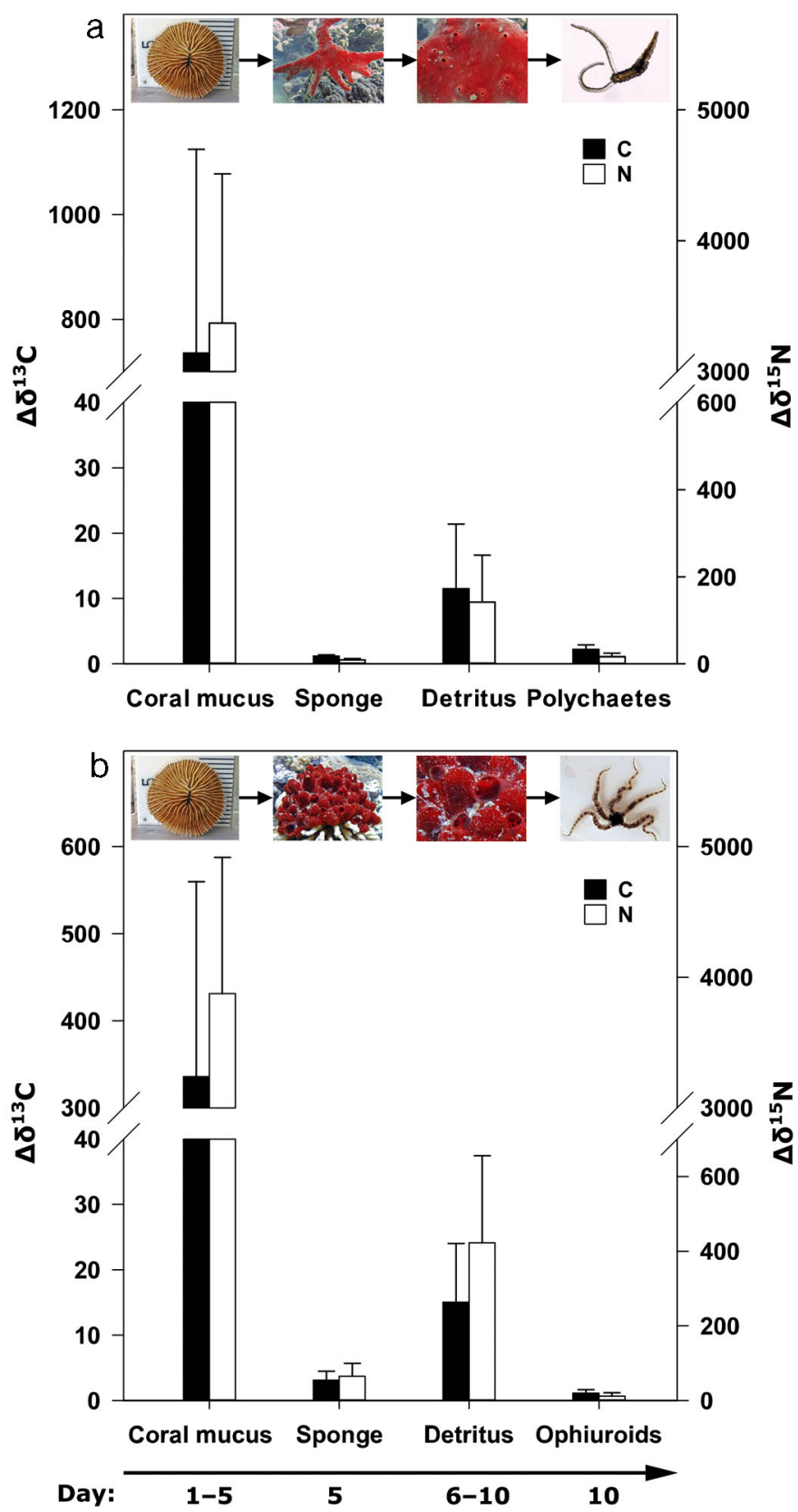

Fig. 1. Stable isotope $\left({ }^{13} \mathrm{C}\right.$ and $\left.{ }^{15} \mathrm{~N}\right)$ enrichment showing trophic transfer of coral-derived organic matter for (a) coral mucus, sponge tissue and detritus of Negombata magnifica, and the polychaete Polydorella smurovi; and (b) coral mucus, sponge tissue and detritus of Mycale fistulifera, and the ophiuroids Ophiothrix savignyi and Ophiocoma scolopendrina. Values presented as mean $\pm \mathrm{SD}$ above-background tracer incorporation $\Delta \delta^{13} \mathrm{C}(\%)$ and $\Delta \delta^{15} \mathrm{~N}(\%)$

(mean $\pm \mathrm{SD}$ ) $3.0 \pm 0.9 \mu \mathrm{mol} \mathrm{C}_{\text {mucus }}$ mmol $\mathrm{C}_{\text {sponge }}{ }^{-1} \mathrm{~d}^{-1}$ and $3.2 \pm 1.6 \mu \mathrm{mol} \mathrm{N}_{\text {mucus }}$ mmol $\mathrm{N}_{\text {sponge }}{ }^{-1} \mathrm{~d}^{-1}$ for $M$. fistulifera and $1.1 \pm 0.1 \mu \mathrm{mol} \mathrm{C}_{\text {mucus }} \mathrm{mmol} \mathrm{C}_{\text {sponge }} \mathrm{e}^{-1}$ and $0.9 \pm 0.2 \mu \mathrm{mol} \mathrm{N}_{\text {mucus }}$ mmol $\mathrm{N}_{\text {sponge }}{ }^{-1} \mathrm{~d}^{-1}$ for $N$. magnifica. After the labelled corals were removed from the experimental set-up, enrichment in ${ }^{13} \mathrm{C}$ and ${ }^{15} \mathrm{~N}$ was detected in the detritus produced by $N$. magnifica and $M$. fistulifera (Fig. 1). Finally, after $5 \mathrm{~d}$ exposure to the labelled sponge detritus, enrichment of ${ }^{13} \mathrm{C}$ and ${ }^{15} \mathrm{~N}$ was detected in the tissues of the detritivores: the polychaete Polydorella smurovi and the ophiuroids Ophiothrix savignyi and Ophiocoma scolopendrina (Fig. 1). In all cases, there was higher enrichment of ${ }^{15} \mathrm{~N}$ than ${ }^{13} \mathrm{C}$, likely due to the higher initial ${ }^{15} \mathrm{~N}$ enrichment in the coral mucus. Despite expected isotope label dilution with each trophic transfer step (e.g. due to respiration and incomplete processing of each labelled source within the time frame of the experiment), the polychaetes and ophiuroids were significantly enriched in ${ }^{13} \mathrm{C}$ and ${ }^{15} \mathrm{~N}$ compared to the controls (polychaetes: Monte Carlo $F_{1,4}=12.33, \mathrm{p}=0.02$ for $\mathrm{C}$ and $F_{1,4}=20.62, \mathrm{p}=0.006$ for $\mathrm{N}$; ophiuroids: $F_{1,24}=15.50, \mathrm{p}=0.001$ for $\mathrm{C}$ and $F_{1,24}=38.94, \mathrm{p}<0.001$ for $\left.\mathrm{N}\right)$. Thus, coral-derived ${ }^{13} \mathrm{C}$ and ${ }^{15} \mathrm{~N}$ were (1) released by the corals, (2) taken up by the sponges, (3) released as sponge detritus, and (4) incorporated by the detritivores. The polychaetes assimilated sponge detritus at higher rates of $32.3 \pm 13.0 \mu \mathrm{mol} \mathrm{C}_{\text {detritus }}$ mmol $\mathrm{C}_{\text {detritivore }}{ }^{-1} \mathrm{~d}^{-1}$ and $24.4 \pm 11.3 \mu \mathrm{mol} \mathrm{N}_{\text {detritus }} \mathrm{mmol} \mathrm{N}_{\text {detritivore }}{ }^{-1} \mathrm{~d}^{-1}$ compared to the ophiuroids $\left(7.6 \pm 6.5 \mu \mathrm{mol} \mathrm{C}_{\text {detritus }} \mathrm{mmol}\right.$ $\mathrm{C}_{\text {detritivore }}{ }^{-1} \mathrm{~d}^{-1}$ and $6.8 \pm 4.1 \mu \mathrm{mol} \mathrm{N}_{\text {detritus }} \mathrm{mmol}$ $\mathrm{N}_{\text {detritivore }}{ }^{-1} \mathrm{~d}^{-1}$; Fig. 2), although the SDs were high. There were no differences in rates between the 2 ophiuroid species, therefore the results were pooled.

Incubations with sponges yielded significantly higher amounts of particulate organic matter (POM) than seawater controls $\left(F_{1,15}=86.02, \mathrm{p}<0.001\right.$ and $F_{1,15}=81.94, \mathrm{p}<0.001$ for $\mathrm{C}$ and $\mathrm{N}$, respectively). On average, detritus production by $N$. magnifica $(15.5 \pm$ $7.2 \mu \mathrm{mol} \mathrm{C}_{\text {org }} \mathrm{cm}^{-3} \mathrm{~d}^{-1}$ and $2.1 \pm 0.9 \mu \mathrm{mol} \mathrm{N} \mathrm{cm}^{-3} \mathrm{~d}^{-1}$ ) was comparable to that of $M$. fistulifera (17.2 \pm $7.5 \mu \mathrm{mol} \mathrm{C}_{\text {org }} \mathrm{cm}^{-3} \mathrm{~d}^{-1}$ and $1.8 \pm 0.4 \mu \mathrm{mol} \mathrm{N} \mathrm{cm} \mathrm{N}^{-3} \mathrm{~d}^{-1}$; Fig. 2). The mean $( \pm \mathrm{SD}) \mathrm{C}: \mathrm{N}$ ratio of the sponge detritus $(7.2 \pm 1.7$ and $6.7 \pm 1.0$ for $N$. magnifica and $M$. fistulifera, respectively) was significantly lower than that of the ambient suspended POM in the water column $\left(10.3 \pm 1.4 ; F_{1,16}=17.16, \mathrm{p}=0.003\right)$.

\section{DISCUSSION}

Here we show that reef sponges facilitate the transfer of coral-derived organic matter to their associated detritivores via the production of sponge detritus, thereby demonstrating all steps of the sponge loop (Fig. 3). Several sponge species are able to convert coral-derived DOM into sponge detritus (Rix et al. 

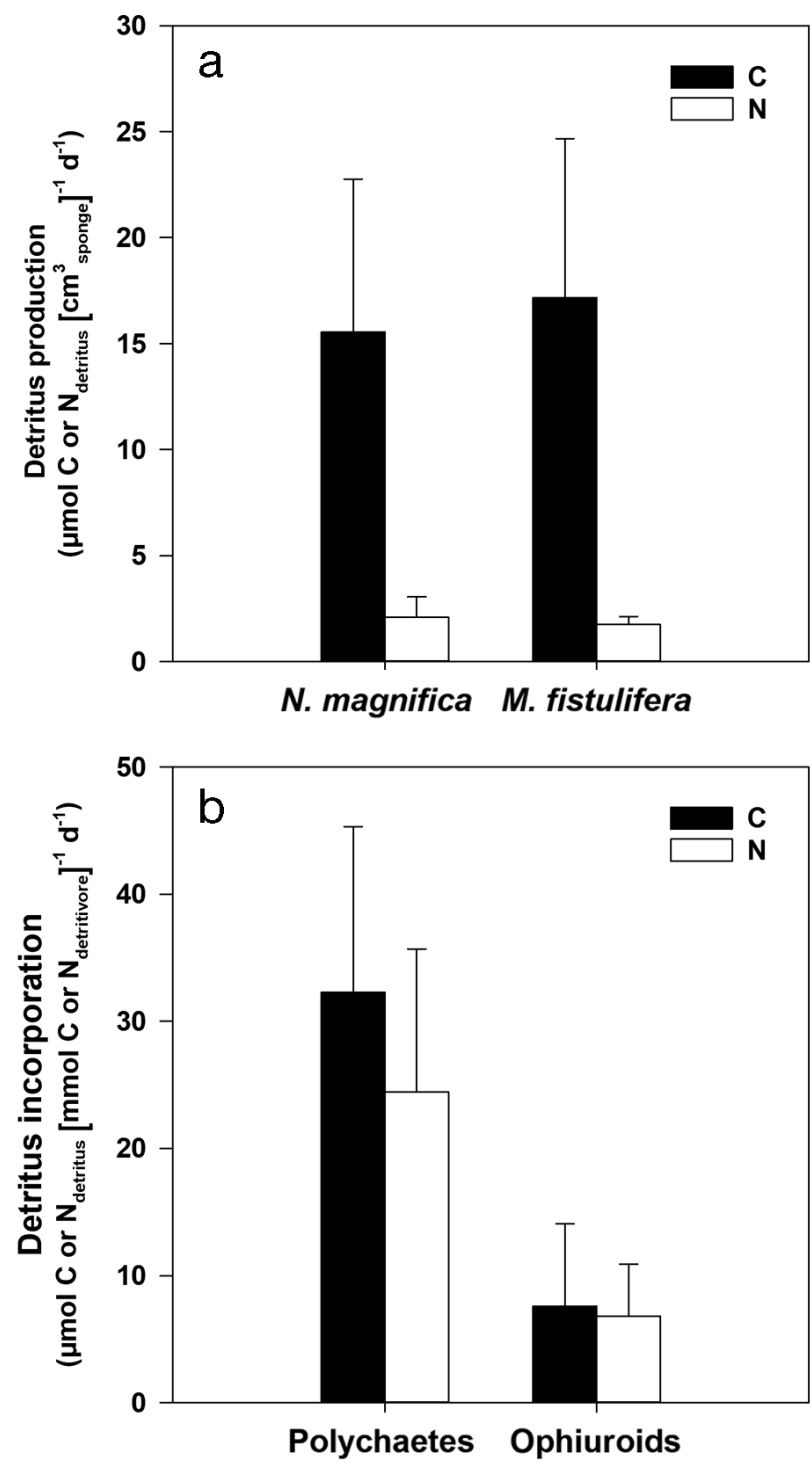

Fig. 2. Rates of (a) detritus production by the 2 sponge species Negombata magnifica and Mycale fistulifera presented as $\mu \mathrm{mol} \mathrm{C}_{\text {detritus }}$ (or $\mathrm{N}_{\text {detritus}}$ ) $\mathrm{cm}^{-3}$ sponge $\mathrm{d}^{-1}(\mathrm{n}=6)$, and (b) incorporation of sponge detritus by the ophiuroids Ophiothrix savignyi and Ophiocoma scolopendrina $(\mathrm{n}=12)$ and the polychaete Polydorella smurovi $(\mathrm{n}=3)$ presented as $\mu \mathrm{mol} \mathrm{C}$ detritus (or $\mathrm{N}_{\text {detritus}}$ ) $\mathrm{mmol} \mathrm{C}_{\text {detritivore }}{ }^{-1}$ (or $\mathrm{N}_{\text {detritivore }}{ }^{-1}$ ) $\mathrm{d}^{-1}$. Data presented as mean $\pm \mathrm{SD}$

2016, 2017), but this study provides direct evidence that organic matter produced by corals is further transferred up the reef food web (Fig. 3). Corals release organic matter as both dissolved and particulate mucus (Crossland 1987, Wild et al. 2004, Tanaka et al. 2009, Naumann et al. 2010), as well as cellular material such as expelled Symbiodinium (HoeghGuldberg et al. 1987, Baghdasarian \& Muscatine 2000). Organic matter could be transferred from corals to sponges by all these pathways, but DOM likely makes up the largest fraction, as the majority ( 56 to $80 \%$ ) of coral mucus dissolves in the water column (Wild et al. 2004), and coral loss of fixed carbon due to expulsion of Symbiodinium is typically negligible $(0.01 \%$; Hoegh-Guldberg et al. 1987) compared with mucus release (up to $\sim 40 \%$; Crossland et al. 1980, Tremblay et al. 2012). Coral-derived organic matter could also be indirectly transferred to sponges via bacteria, which can also consume coral mucus (Ferrier-Pagès et al. 2000, Wild et al. 2010, Tanaka et al. 2011). Here, DOC measurements confirmed the uptake of coral-derived DOM by the experimental sponges, consistent with previous studies showing the dissolved fraction of coral mucus is readily taken up by several reef sponges (Rix et al. 2017). However, potential uptake of coral-derived POM or microbialmediated transfer of coral mucus could additionally contribute to sponge recycling of coral-derived organic matter and further facilitate energy and nutrient retention within coral reefs (de Goeij et al. 2013, Rix et al. 2016). At our study site in the northern Red Sea, corals are the dominant primary producers supplying DOM to the sponge loop (Cardini et al. 2016, van Hoytema et al. 2016), but on coral reefs dominated by macroalgae, the main source of DOM for the sponge loop may rather be supplied by algae (Fig. 3). Algae not only typically release more labile DOM than corals (Haas et al. 2011, Mueller et al. 2014b), but sponges also appear to process algalderived DOM at a higher rate than coral-derived DOM (Rix et al. 2017), suggesting increased algal cover may enhance DOM cycling though the sponge loop. Since inorganic nutrient release by sponges can additionally enhance algal growth (Slattery et al. 2013, Easson et al. 2014), it has also been hypothesized that this reciprocal coral-algae nutrient recycling may result in a positive feedback loop further promoting the growth of sponges and algae, potentially at the expense of corals (Pawlik et al. 2016). Indeed, numerous studies have highlighted how DOM released by corals versus algae exerts differing effects on reef functioning by altering microbial activity (Barott \& Rohwer 2012, Haas et al. 2013, 2016, Nelson et al. 2013); however, the potential effects due to altered nutrient cycling by sponges remains poorly explored.

The encrusting sponge Mycale fistulifera was previously shown to convert coral mucus into detritus (Rix et al. 2016, 2017), but interestingly, we also found transfer of coral-derived organic matter into the detritus released by the massive branching sponge Negombata magnifica. The transfer of DOM into sponge detritus has so far only been documented 


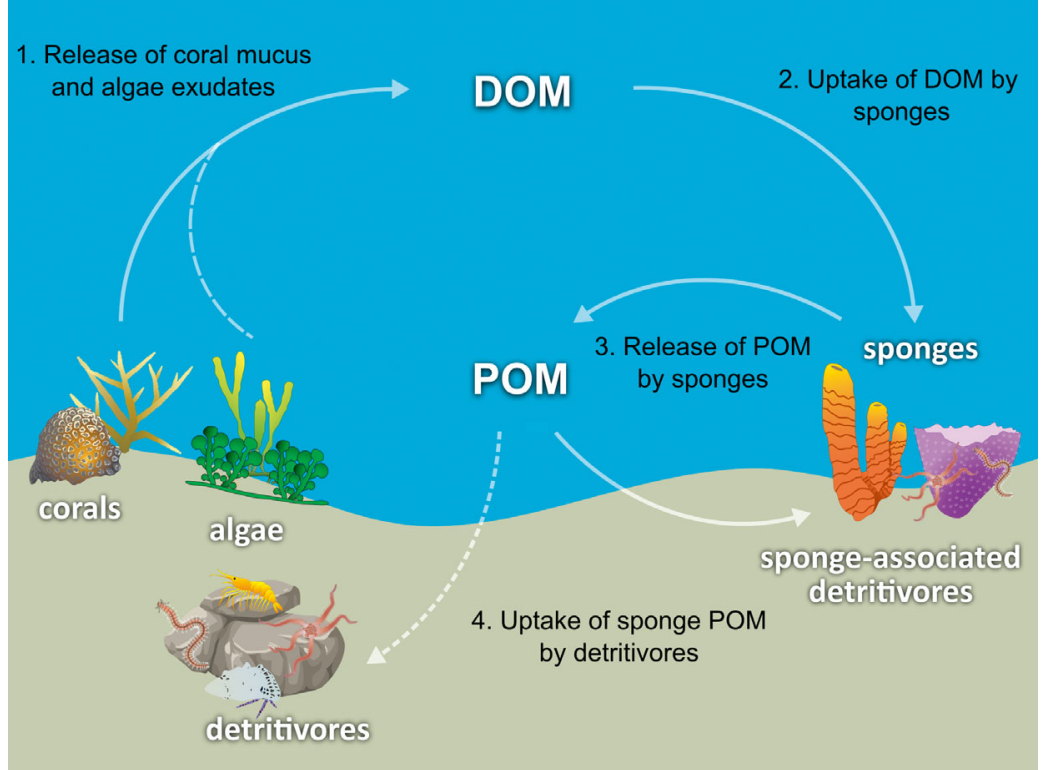

Fig. 3. The steps of the sponge loop pathway: (1) corals and algae release exudates as dissolved organic matter (DOM), (2) sponges take up DOM, (3) sponges release detrital particulate organic matter (POM), (4) sponge detritus (POM) is taken up by sponge-associated and free-living detritivores. Pathways in solid arrows indicate the steps of trophic transfer of coral-derived carbon and nitrogen demonstrated in the present study. Dashed arrows represent steps of trophic transfer from the literature: (-- ) Rix et al. (2017) and (---) de Goeij et al. (2013)

for encrusting sponges (de Goeij et al. 2013, Rix et al. $2016,2017)$, and it has been suggested that high cell shedding and detritus production may be restricted to these thin encrusting species whose growth is limited by high competition for free substrate (e.g. Buss \& Jackson 1979). Since the upward growth of massive sponges is not similarly constrained, they are expected to invest more resources into growth rather than high biomass turnover (Pawlik et al. 2016). Despite the differences in growth form, we found comparable detritus production rates by the 2 sponges, although with considerable intraspecific variability. Sponge detritus is hypothesized to be largely due to high cell turnover and shedding, particularly of sponge choanocyte cells (de Goeij et al. 2009, Alexander et al. 2014). However, sponges may also release detritus by ejecting waste products and incompletely digested food (Maldonado 2016) or via other mechanisms such as mucus production in response to sedimentation (Bell et al. 2015, Biggerstaff et al. 2017). Sponge cell turnover and shedding is reduced under suboptimal food conditions (Alexander et al. 2015b) and in wounded sponges (Alexander et al. 2015a), suggesting a complex interplay of factors such as food availability, predation, reproductive status, growth rate and sponge health may govern detritus production. Interestingly, there was higher enrichment of ${ }^{13} \mathrm{C}$ and ${ }^{15} \mathrm{~N}$ in the sponge detritus compared with the sponge tissue (Fig. 1). We hypothesize that coral-derived $\mathrm{C}$ and $\mathrm{N}$ is preferentially incorporated into highly active cells and tissues with a high turnover rate that disproportionately contribute to sponge detritus. This would be consistent with previous studies that found that up to approximately $40 \%$ of assimilated DOM is released as detritus within 3 to $12 \mathrm{~h}$, indicating rapid turnover of assimilated DOM (de Goeij et al. 2013, Rix et al. 2017).

The enrichment of ${ }^{13} \mathrm{C}$ and ${ }^{15} \mathrm{~N}$ in the ophiuroids and polychaete confirms the last step of the sponge loop - the sponge-mediated transfer of coral-derived organic matter to higher trophic levels (Fig. 3). There are 2 possible pathways for this transfer: (1) predation on living sponge tissue or (2) uptake of sponge detritus. Spionid polychaetes (Dauer et al. 1981, Williams \& McDermott 1997), as well as Ophiocoma scolopendrina and Ophiothrix ophiuroids (Magnus 1965, Warner \& Woodley 1975) are welldescribed suspension or deposit feeders. The 2 ophiuroids were observed feeding on detritus on the sponge surface (L. Rix pers. obs.), as reported for other ophiuroid-sponge associations (Hendler 1984). Video analysis of Polydorella smurovi demonstrated characteristic spionid feeding behaviour by which particles are captured using a pair of tentaculate palps and transported to the pharynx (Naumann et al. 2016). The absence of scars or bite marks further renders direct consumption of sponge tissue unlikely; thus, we consider the enrichment of ${ }^{13} \mathrm{C}$ and ${ }^{15} \mathrm{~N}$ in the detritivores to be due to detritus feeding. Detritus incorporation rates were comparable to those for sediment-dwelling sponge detritus feeders in the Caribbean (de Goeij et al. 2013). Combined with observations of sponge detritus feeding by spongeassociated holothuroids (Hammond \& Wilkinson 1985), collectively this shows sponge detritus is utilized by a wide variety of reef fauna. Sponge detritus may be particularly important for obligate and nonmotile sponge associates (e.g. Polydorella polychaetes), as continuous detritus production by sponges 
could help alleviate temporal fluctuations in food availability for these organisms that are reliant on their habitat to provide sufficient access to food. Nevertheless, mobile organisms also have to balance the trade-off between predator avoidance and foraging activity (e.g. Brooker et al. 2013, Catano et al. 2016), and therefore finding shelter that also supplies food can be highly advantageous (Duffy \& Hay 1994). Measurable detrital $\mathrm{C}_{\text {org }}$ and $\mathrm{N}$ production by the 2 sponges further supports the potential for sponge detritus to be an important resource for associated fauna, but additional studies are required to determine its quantitative importance to their diet. Food quality also influences its potential value (Andersen et al. 2007, Mitra \& Flynn 2007), and less degraded detritus is typically of higher nutritional value due to selective removal of more labile fractions during degradation processes (Bowen 1987). High cell turnover and shedding is hypothesized to be the major source of sponge detritus (de Goeij et al. 2009, Alexander et al. 2014), and these freshly shed cells may be relatively undegraded. This is supported by the significantly lower $\mathrm{C}: \mathrm{N}$ ratios of the sponge detritus compared with ambient suspended POM in the water column. However, sponge detritus also contains metabolic waste and incompletely digested food, which may be less labile (Maldonado 2016). Thus, compositional analysis would better establish its nutritional value. Nevertheless, we show that sponges generate food for their inhabitants - and provide them access to coral-derived energy and nutrients - as an added benefit to consider when interpreting sponge-detritivore associations. The consequences for the sponge host are less clear, but by clearing the sponge of debris, the associations may be mutualistic (Hendler 1984, Martin \& Britayev 1998). However, empirical evidence of a measurable benefit (e.g. in terms of increased growth rate or reproductive output) to the sponge is lacking and could be highly context-dependent (Henkel \& Pawlik 2014).

Detritivores occupy an important role in reef food webs by recycling detritus to higher trophic levels. Ophiuroids, for example, experience heavy predation, particularly by reef fish (Hendler 1984, Aronson 1988, Henkel \& Pawlik 2005), thereby offering a direct pathway by which coral-derived DOM could be further transferred up the reef food web. A large fraction of reef organic matter passes through the detrital food web and these detrital pathways play an important role in recycling primary production (Alongi 1988, Hansen et al. 1992, Max et al. 2013, McMahon et al. 2016). Empirical evidence is needed to quantify the importance of the sponge loop within reef food webs, but DOM uptake by cryptic sponges is estimated to approximate gross reef primary production (de Goeij \& van Duyl 2007), and trophic models suggest it may have cascading effects on energy transfer to higher trophic levels leading to altered fish production (Silveira et al. 2015). Further, the sponge loop may contribute to the efficient nutrient cycling that enables coral reefs to maintain high productivity in oligotrophic conditions (de Goeij et al. 2013). While the microbial loop also facilitates the transfer of DOM to higher trophic levels, it may rather largely fuel the pelagic food web (Worden et al. 2015), whereas transfer of DOM to higher trophic levels via the sponge loop may facilitate the recycling of reef-derived DOM to sponge-associated and other benthic fauna and thereby promote benthic productivity. Thus, this novel trophic link between corals, sponges and their associated detritivores may provide an example of how facilitative interspecific interactions not only enhance resource use between partners (Stachowicz 2001, Bruno et al. 2003), but may ultimately influence ecosystem productivity. In conclusion, there is an urgent need to recognize the pivotal role of sponges, so far largely neglected key players, within coral reef food webs.

Acknowledgements. We are grateful to V. Bednarz, U. Cardini, S. Helber, N. van Hoytema, and the staff at the Marine Science Station for fieldwork assistance and logistical support. We also acknowledge B. Fuchs and S. Dyksma for assistance with the generation of the flow cytometry data and R. van Soest for sponge identification. Funding was provided by the German Leibniz Association (WGL) and the European Research Council (ERC) under the European Union's Horizon 2020 research and innovation programme (grant agreement \#715513 to J.M.G.).

\section{LITERATURE CITED}

Alexander BE, Liebrand K, Osinga R, van der Geest HG and others (2014) Cell turnover and detritus production in marine sponges from tropical and temperate benthic ecosystems. PLOS ONE 9:e109486

Alexander BE, Achlatis M, Osinga R, van der Geest HG, Cleutjens JPM, Schutte B, de Goeij JM (2015a) Cell kinetics during regeneration in the sponge Halisarca caerulea: How local is the response to tissue damage? PeerJ 3:e820

Alexander BE, Mueller B, Vermeij MJA, van der Geest HHG, de Goeij JM (2015b) Biofouling of inlet pipes affects water quality in running seawater aquaria and compromises sponge cell proliferation. PeerJ 3:e1430

Alongi DM (1988) Detritus in coral reef ecosystems: fluxes and fates. Proc 6th Int Coral Reef Symp, Townsville, $1: 29-36$

Andersen T, Faerovig PJ, Hessen DO (2007) Growth rate 
versus biomass accumulation: different roles of food quality and quantity for consumers. Limnol Oceanogr 52: 2128-2134

Anderson MJ, Gorley RN, Clarke KR (2008) PERMANOVA+ for PRIMER: guide to software and statistical methods. Primer-E, Plymouth

Aronson RB (1988) Palatability of five Caribbean ophiuroids. Bull Mar Sci 43:93-97

Baghdasarian G, Muscatine L (2000) Preferential expulsion of dividing algal cells as a mechanism for regulating algal-cnidarian symbiosis. Biol Bull 199:278-286

Barott KL, Rohwer FL (2012) Unseen players shape benthic competition on coral reefs. Trends Microbiol 20:621-628

Barrón C, Duarte CM (2009) Dissolved organic matter release in a Posidonia oceanica meadow. Mar Ecol Prog Ser 374:75-84

Bell JJ, McGrath E, Biggerstaff A, Bates T, Bennett H, Marlow J, Shaffer M (2015) Sediment impacts on marine sponges. Mar Pollut Bull 94:5-13

Biggerstaff A, Smith DJ, Jompa J, Bell JJ (2017) Metabolic responses of a phototrophic sponge to sedimentation supports transitions to sponge-dominated reefs. Sci Rep 7:2725

Bowen SH (1987) Composition and nutritional value of detritus. In: Moriarty DJW, Pullin RSV (eds) Detritus and microbial ecology in aquaculture. ICLARM Conf Proc 14. International Center for Living Aquatic Resource Management, Manila, Philippines, p 192-216

Briand MJ, Bonnet X, Guillou G, Letourneur Y (2016) Complex food webs in highly diversified coral reefs: insights from $\delta^{13} \mathrm{C}$ and $\delta^{15} \mathrm{~N}$ stable isotopes. Food Webs 8:12-22

Brooker RM, Munday PL, McLeod IM, Jones GP (2013) Habitat preferences of a corallivorous reef fish: predation risk versus food quality. Coral Reefs 32:613-622

Bruno JF, Stachowicz JJ, Bertness MD (2003) Inclusion of facilitation into ecological theory. Trends Ecol Evol 18: 119-125

Buss LW, Jackson JBC (1979) Competitive networks: nontransitive competitive relationships in cryptic coral reef environments. Am Nat 113:223-234

* Cardini U, Bednarz VN, van Hoytema N, Rovere A, Naumann MS, Al-Rshaidat MMD, Wild C (2016) Budget of primary production and dinitrogen fixation in a highly seasonal Red Sea coral reef. Ecosystems 19:771-785

Catano LB, Rojas MC, Malossi RJ, Peters JR, Heithaus MR, Fourqurean JW, Burkepile DE (2016) Reefscapes of fear: predation risk and reef heterogeneity interact to shape herbivore foraging behaviour. J Anim Ecol 85:146-156

Clarke KR, Gorley RN (2006) PRIMER v6: user manual/tutorial. PRIMER-E, Plymouth

* Costello MJ, Myers AA (1987) Amphipod fauna of the sponge Halichondria panicea and Hymeniacidon perleve in Lough Hyne, Ireland. Mar Ecol Prog Ser 41:115-121

Crossland CJ (1987) In situ release of mucus and DOC-lipid from the corals Acropora variabilis and Stylophora pistillata in different light regimes. Coral Reefs 6:35-42

Crossland CJ, Barnes DJ, Borowitzka MA (1980) Diurnal lipid and mucus production in the staghorn coral Acropora acuminata. Mar Biol 60:81-90

Dauer DM, Maybury CA, Ewing RM (1981) Feeding behaviour and general ecology of several spionid polychaetes from the Chesapeake Bay. J Exp Mar Biol Ecol 54:21-38

de Goeij J, van Duyl F (2007) Coral cavities are sinks of dissolved organic carbon (DOC). Limnol Oceanogr 52: 2608-2617 de Goeij JM, van den Berg H, van Oostveen MM, Epping EHG, van Duyl FC (2008) Major bulk dissolved organic carbon (DOC) removal by encrusting coral reef cavity sponges. Mar Ecol Prog Ser 357:139-151

de Goeij JM, de Kluijver A, van Duyl FC, Vacelet J and others (2009) Cell kinetics of the marine sponge Halisarca caerulea reveal rapid cell turnover and shedding. J Exp Biol 212:3892-3900

de Goeij JM, van Oevelen D, Vermeij MJA, Osinga R, Middelburg JJ, de Goeij AFPM, Admiraal W (2013) Surviving in a marine desert: the sponge loop retains resources within coral reefs. Science 342:108-110

* Duarte LFL, Nalesso RC (1996) The sponge Zygomycale parishii (Bowerbank) and its endobiotic fauna. Estuar Coast Shelf Sci 42:139-151

* Duffy JE (1992) Host use patterns and demography in a guild of tropical sponge-dwelling shrimps. Mar Ecol Prog Ser 90:127-138

*Duffy JE, Hay ME (1994) Herbivore resistance to seaweed chemical defense: the roles of mobility and predation risk. Ecology 75:1304-1319

Duriš Z, Horká I, Juračka PJ, Petrusek A, Sandford F (2011) These squatters are not innocent: the evidence of parasitism in sponge-inhabiting shrimps. PLOS ONE 6: e21987

Easson CG, Slattery M, Baker DM, Gochfeld DJ (2014) Complex ecological associations: competition and facilitation in a sponge-algal interaction. Mar Ecol Prog Ser 507: 153-167

Elliott KJ, Mariscal NR (2001) Coexistence of nine anemonefish species: differential host and habitat utilization, size and recruitment. Mar Biol 138:23-36

Ferrier-Pagès C, Leclercq N, Jaubert J, Pelegri SP (2000) Enhancement of pico- and nanoplankton growth by coral exudates. Aquat Microb Ecol 21:203-209

Glynn PW (2004) High complexity food webs in low-diversity eastern Pacific reef-coral communities. Ecosystems $7: 358-367$

*Haas AF, Nelson CE, Wegley Kelly L, Carlson CA and others (2011) Effects of coral reef benthic primary producers on dissolved organic carbon and microbial activity. PLOS ONE 6:e27973

*Haas AF, Nelson CE, Rohwer F, Wegley Kelly L and others (2013) Influence of coral and algal exudates on microbially mediated reef metabolism. PeerJ 1:e108

Haas AF, Fairoz MFM, Wegley Kelly L, Nelson CE and others (2016) Global microbialization of coral reefs. Nat Microbiol 1:16042

Hammond LS, Wilkinson CR (1985) Exploitation of sponge exudates by coral reef holothuroids. J Exp Mar Biol Ecol 94:1-9

*Hansen JA, Klumpp DW, Alongi DM, Dayton PK, Riddle MJ (1992) Detrital pathways in a coral reef lagoon. 2. Detritus deposition, benthic microbial biomass and production. Mar Biol 113:363-372

* Harborne AR, Rogers A, Bozec YM, Mumby PJ (2017) Multiple stressors and the functioning of coral reefs. Annu Rev Mar Sci 9:445-468

*Hendler G (1984) The association of Ophiothric lineata and Callyspongia vaginalis: a brittlestar-sponge cleaning symbiosis. Mar Ecol 5:9-27

*Henkel TP, Pawlik JR (2005) Habitat use by spongedwelling brittlestars. Mar Biol 146:301-313

*Henkel TP, Pawlik JR (2014) Cleaning mutualist or parasite? Classifying the association between the brittlestar 
Ophiothrix lineata and the Caribbean reef sponge Callyspongia vaginalis. J Exp Mar Biol Ecol 454:42-48

Hoegh-Guldberg O, McCloskey LR, Muscatine L (1987) Expulsion of zooxanthellae by symbiotic cnidarians from the Red Sea. Coral Reefs 5:201-204

James DB, Pearse JS (1969) Echinoderms from the Gulf of Suez and the northern Red Sea. J Mar Biol Assoc India 11:78-125

Magnus DBE (1967) Ecological and ethological studies and experiments on the echinoderms of the Red Sea. Proc Int Conf Tropical Oceanography, Nov 17-24, 1965, Miami. Stud Trop Oceanogr 5:635-664

Maldonado M (2016) Sponge waste that fuels marine oligotrophic food webs: a re-assessment of its origin and nature. Mar Ecol 37:477-491

Marie D, Partensky F, Vaulot D, Brussard C (1999) Enumeration of phytoplankton, bacteria, and viruses in marine samples. In: Robinson JPEA (ed) Current protocols in cytometry. John Wiley \& Sons, New York, NY, p 11.11.1-11.11.15

Martin D, Britayev TA (1998) Symbiotic polychaetes: review of known species. Oceanogr Mar Biol Annu Rev 36: 217-340

Max LM, Hamilton SL, Gaines SD, Warner RR (2013) Benthic processes and overlying fish assemblages drive the composition of benthic detritus on a central Pacific coral reef. Mar Ecol Prog Ser 482:181-195

McMahon KW, Thorrold SR, Houghton LA, Berumen ML (2016) Tracing carbon flow through coral reef food webs using a compound-specific stable isotope approach. Oecologia 180:809-821

McMurray SE, Johnson ZI, Hunt DE, Pawlik JR, Finelli CM (2016) Selective feeding by the giant barrel sponge enhances foraging efficiency. Limnol Oceanogr 61: 1271-1286

Meroz E, Ilan M (1995) Cohabitation of a coral reef sponge and a colonial scyphozoan. Mar Biol 124:453-459

Mitra A, Flynn KJ (2007) Importance of interactions between food quality, quantity, and gut transit time on consumer feeding, growth, and trophic dynamics. Am Nat 169: 632-646

Morganti T, Coma R, Yahel G, Ribes M (2017) Trophic niche separation that facilitates co-existence of high and low microbial abundance sponges is revealed by in situ study of carbon and nitrogen fluxes. Limnol Oceanogr 62: 1963-1983

* Mueller B, de Goeij JM, Vermeij MJA, Mulders Y, van der Ent E, Ribes M, van Duyl FC (2014a) Natural diet of coral-excavating sponges consists mainly of dissolved organic carbon (DOC). PLOS ONE 9:e90152

Mueller B, van der Zande RM, van Leent PJM, Meesters EH, Vermeij MJA, van Duyl FC (2014b) Effect of light availability on dissolved organic carbon release by Caribbean reef algae and corals. Bull Mar Sci 90:875-893

Kunday PL, Jones GP, Caley MJ (1997) Habitat specialisation and the distribution and abundance of coraldwelling gobies. Mar Ecol Prog Ser 152:227-239

Naumann M, Haas A, Struck U, Mayr C, El-Zibdah M, Wild C (2010) Organic matter release by dominant hermatypic corals of the Northern Red Sea. Coral Reefs 29:649-659

Naumann MS, Rix L, Al-Horani FA, Wild C (2016) Indications of mutual functional benefits within a polychaetesponge association in the northern Red Sea. Bull Mar Sci 92:377-378

Nelson CE, Goldberg SJ, Wegley Kelly L, Haas AF, Smith
JE, Rohwer F, Carlson CA (2013) Coral and macroalgal exudates vary in neutral sugar composition and differentially enrich reef bacterioplankton lineages. ISME J 7: 962-979

Oshel PE, Steele DH (1985) Amphipod Paramphithose hystrix: a micropredator on the sponge Haliclona ventilabrum. Mar Ecol Prog Ser 23:307-309

Pawlik JR (1983) A sponge-eating worm from Bermuda: Branchiosyllis oculata (Polychaeta, Syllidae). Mar Ecol 4: 65-79

Pawlik JR, Burkepile DE, Thurber RV (2016) A vicious circle? Altered carbon and nutrient cycling may explain the low resilience of Caribbean coral reefs. Bioscience 66: 470-476

Pearse AS (1950) Notes on the inhabitants of certain sponges at Bimini. Ecology 31:149-151

R Core Team (2012) R: a language and environment for statistical computing. R Foundation for Statistical Computing, Vienna

Rix L, de Goeij JM, Mueller CE, Struck U and others (2016) Coral mucus fuels the sponge loop in warm- and coldwater coral reef ecosystems. Sci Rep 6:18715

Rix L, de Goeij JM, van Oevelen D, Struck U, Al-Horani FA, Wild C, Naumann MS (2017) Differential recycling of coral and algal dissolved organic matter via the sponge loop. Funct Ecol 31:778-789

* Silveira CB, Silva-Lima AW, Francini-Filho RB, Marques JSM and others (2015) Microbial and sponge loops modify fish production in phase-shifting coral reefs. Environ Microbiol 17:3832-3846

* Slattery M, Gochfeld DJ, Easson CG, O'Donahue LRK (2013) Facilitation of coral reef biodiversity and health by cave sponge communities. Mar Ecol Prog Ser 476:71-86

Stachowicz JJ (2001) Mutualism, facilitation, and the structure of ecological communities. Bioscience 51:235-246

*Taghon GL, Nowell ARM, Jumars PA (1980) Induction of suspension feeding in spionid polychaetes by high particulate fluxes. Science 210:562-564

* Tanaka Y, Miyajima T, Umezawa Y, Hayashibara T, Ogawa H, Koike I (2009) Net release of dissolved organic matter by the scleractinian coral Acropora pulchra. J Exp Mar Biol Ecol 377:101-106

พ Tanaka Y, Ogawa H, Miyajima T (2011) Production and bacterial decomposition of dissolved organic matter in a fringing coral reef. J Oceanogr 67:427-437

*Tremblay P, Grover R, Maguer JF, Legendre L, FerrierPagès C (2012) Autotrophic carbon budget in coral tissue: a new ${ }^{13} \mathrm{C}$-based model of photosynthate translocation. J Exp Biol 215:1384-1393

van Hoytema N, Bednarz VN, Cardini U, Naumann MS, AlHorani FA, Wild C (2016) The influence of seasonality on benthic primary production in a Red Sea coral reef. Mar Biol 163:52

Warner GF, Woodley JD (1975) Suspension-feeding in brittle-star Ophiothrix fragilis. J Mar Biol Assoc UK 55: 199-210

Westinga E, Hoetjes PC (1981) The intrasponge fauna of Spheciospongia vesparia (Porifera, Demospongiae) at Curaçao and Bonaire. Mar Biol 62:139-150

*Wild C, Huettel M, Klueter A, Kremb S, Rasheed M, Jorgensen B (2004) Coral mucus functions as an energy carrier and particle trap in the reef ecosystem. Nature 428 : 66-70

Wild C, Niggl W, Naumann MS, Haas AF (2010) Organic matter release by Red Sea coral reef organisms-poten- 
tial effects on microbial activity and in situ $\mathrm{O}_{2}$ availability. Mar Ecol Prog Ser 411:61-71

Williams JD (2004) Reproduction and morphology of Polydorella (Polychaeta: Spionidae), including the description of a new species from the Philippines. J Nat Hist 38: 1339-1358

Williams JD, McDermott JJ (1997) Feeding behavior of Dipolydora commensalis (Polychaeta: Spionidae): particle capture, transport, and selection. Invertebr Biol 116: 115-123

Editorial responsibility: Joseph Pawlik, Wilmington, North Carolina, USA
Worden AZ, Follows MJ, Giovannoni SJ, Wilken S, Zimmerman AE, Keeling PJ (2015) Rethinking the marine carbon cycle: factoring in the multifarious lifestyles of microbes. Science 347:1257594

Wulff JL (2006) Ecological interactions of marine sponges. Can J Zool 84:146-166

* Yahel G, Sharp J, Marie D, Hase C, Genin A (2003) In situ feeding and element removal in the symbiont-bearing sponge Theonella swinhoei: bulk DOC is the major source for carbon. Limnol Oceanogr 48:141-149

Submitted: July 11, 2017; Accepted: December 4, 2017 Proofs received from author(s): February 7, 2018 